\title{
Characterization of Pythium spp. Associated with Corn and Soybean Seed and Seedling Disease in Ohio
}

\author{
K. D. Broders, P. E. Lipps, P. A. Paul, and A. E. Dorrance, Department of Plant Pathology, The Ohio State Uni- \\ versity, Wooster 44691
}

\begin{abstract}
Broders, K. D., Lipps, P. E., Paul, P. A., and Dorrance, A. E. 2007. Characterization of Pythium spp. associated with corn and soybean seed and seedling disease in Ohio. Plant Dis. 91:727-735.

Cool, moist conditions in combination with minimum tillage, earlier planting, and recent shifts in commercial fungicide seed-treatment active ingredients have led to an increase in corn (Zea mays) and soybean (Glycine max) seedling establishment problems. This situation resulted in an investigation of Pythium spp. associated with seed and seedling diseases. Samples of diseased corn and soybean seedlings were collected from 42 production fields in Ohio. All isolates of Pythium recovered were identified to species using morphological and molecular techniques and evaluated in an in vitro pathogenicity assay on both corn and soybean seed, and a subset of the isolates was tested for sensitivity to fungicides currently used as seed treatments. Eleven species and two distinct morphological groups of Pythium were identified, of which six species were moderately to highly pathogenic on corn seed and nine species were highly pathogenic on soybean seed. There was significant variation $(P<0.05)$ in sensitivity to mefenoxam, azoxystrobin, trifloxystrobin, and captan both across and within species. Multiple species of Pythium had the capacity to reduce germination of both corn and soybean seed. Results indicated that mefenoxam, azoxystrobin, trifloxystrobin, or captan, when used individually, may not inhibit all pathogenic species of Pythium found in Ohio soils.
\end{abstract}

Additional keywords: ITS, SHAM

Infection of corn (Zea mays L.) or soybean (Glycine max (L.) Merr.) seed or seedlings by Pythium spp. can result in pre- or post-emergence damping-off, but some plants, given more favorable growing conditions, may continue to grow despite the presence of root infection (8). Although plants may survive the initial infection, nonlethal wounds caused by the pathogen may lead to reduced root and shoot growth, resulting in reduced plant vigor and yield, especially under periods of stress conditions. A recent shift in planting dates for corn has occurred, starting on average 8 days earlier and finishing 16 days earlier than during the 10 years previous (33). Earlier planting means seed are more likely to be placed under environmental conditions unfavorable for rapid germination, thus increasing the level of stress on the seed and, more importantly, the length of time fungicide seed treatments must provide adequate protection. The combination of these factors may have contributed to the increased number of emergence problems recently experienced by growers.

Corresponding author: A. E. Dorrance

E-mail: dorrance.1@osu.edu

Accepted for publication 6 January 2007.

doi:10.1094/PDIS-91-6-0727

(C) 2007 The American Phytopathological Society
Pythium spp. frequently are associated with seed and seedling diseases, and commonly have been isolated from corn (30) and soybean $(5,11,32)$ early in the season when the soils are predominantly moist and cool. In some cases, the increased prevalence of seedling disease such as damping-off and the relative abundance of pathogenic Pythium spp. have been associated with the increase in reduced tillage practices (29). Reduced tillage leaves more of the soil covered with crop debris and prevents rapid drying and warming of the soil in spring, slowing the germination and growth of young seedlings $(12,39)$. This contributes to an increase in the Pythium populations in the soil (29). Several $P y$ thium spp. may be isolated from a single piece of root tissue or from the soil surrounding the roots. This makes it difficult to attribute the disease causal agent to an individual species, because both pathogens and saprophytes may be recovered. Species of Pythium also are known to vary in pathogenicity on soybean $(9,43)$, corn $(7,30)$, and wheat (14). This complicates the development of effective seedling disease management strategies because, in many cases, multiple species must be managed. To achieve adequate control, each crop must have appropriate genes for resistance or fungicides must have activity against multiple species of Pythium.

One of the major challenges of managing diseases caused by more than one spe- cies of Pythium is the problem of properly identifying all of the species associated with the disease. Difficulty in correctly identifying Pythium spp. hampers attempts to determine how many different species are present in a field, which species are the most abundant, and which are the most pathogenic. Earlier studies in Ohio isolated and identified Pythium catenulatum Matthews, $P$. irregulare Buisman, $P$. paroecandrum Drech., P. splendens H. Braun, and $P$. torulosum Coker \& F. Patterson from soybean seedlings using a soil baiting technique (9); and $P$. arrhenomanes Drechs., $P$. dissotocum Drechs., $P$. graminicola Subramanian, $P$. ultimum Trow, and P. torulosum from corn seedlings $(21,30)$.

Currently, seedling diseases and seed rots are managed by planting seed treated with a combination of fungicides. Metalaxyl or mefenoxam were applied to seed predominantly for the management of Pythium and other oomycetes, whereas captan, a broader-spectrum fungicide, was used to manage Pythium, Fusarium, and Rhizoctonia spp. Newer fungicide seed treatments such as the strobilurins, azoxystrobin and trifloxystrobin, with activity against a broad spectrum of pathogens, recently were introduced as companion fungicides to improve efficacy. In addition, fludioxonil, with activity against Fusarium spp., also was added to some seedtreatment products. In many commercial seed treatments, captan has been replaced by one of the strobilurins, fludioxonil, or both. In addition, the continued use of metalaxyl and mefenoxam for the control of Pythium spp. has led to increased insensitivity of several Pythium spp. in some crop systems $(4,6,26,37)$. Strobilurin fungicides differ in their mode of action from metalaxyl and mefenoxam; however, like metalaxyl and mefenoxam the activity of the strobilurins is site specific (42). Thus, the continued use of these fungicides may lead to reduced efficacy due to increased insensitivity of the Pythium population. Currently, little is known about the level of sensitivity of Pythium spp. to the strobilurin fungicides. However, there have been several reports of other fungi, such as Fusarium spp. (13) and Alternaria alternata $(24,31)$, with decreased sensitivity to the different strobilurin fungicides, and that risk may be associated with target-site mutations $(3,36)$. It also is proposed that some soilborne pathogens may constitutively express their cytochrome and alter- 
native oxidase respiratory pathways $(15,16)$, enabling them to continue production of ATP and, hence, appear resistant to strobilurin fungicides.

The objectives of this study were to (i) isolate and identify Pythium spp. associated with corn and soybean seed and seedling diseases in Ohio, (ii) determine the pathogenicity of isolates on both corn and soybean seed, and (iii) determine the level of sensitivity of the Pythium spp. to mefenoxam, trifloxystrobin, azoxystrobin, and captan.

\section{MATERIALS AND METHODS}

Isolation and identification. Diseased soybean and corn seedlings were collected from fields with reports of emergence problems during the spring of 2004 and 2005. Sections of root or shoot tissue from diseased seedlings were placed between two paper towels and pressed using a rolling pin to remove excess water, and then tissue was placed onto water agar (WA) (20 g of agar per liter). Isolates with characteristic coenocytic hyphae, typical of oomycetes, were transferred as hyphal tips to a dilute V8 media containing pentachloronitrobenzene, iprodione, benlate, neomycin sulfate, and chloramphenicol (PIBNC; 34) that is selective for Oomycetes. A single hyphal tip from the PIBNC culture of each isolate then was transferred to potato-carrot agar (PCA) (38). For longterm storage, each isolate was transferred to a slant vial containing $15 \mathrm{ml}$ of PCA, allowed to colonize the agar for 10 days, covered with sterile mineral oil, and then stored at $10^{\circ} \mathrm{C}$. For identification, isolates were cultured on PCA and in water-grassblade cultures as described by Waterhouse (40). Isolates were identified by observing morphological characteristics of oogonia, antheridia, and sporangia using the standard keys by van der Plaats-Niterink (38), Waterhouse (40), and Middleton (23). Isolates which did not produce all the reproductive structures necessary for conclusive species identification were grouped according to the similarity in structures available and the mycelial growth pattern on PCA.

DNA extraction, polymerase chain reaction, and sequence analysis. The internal transcribed spacer (ITS) sequence from at least one representative isolate of each putative species and each unidentified group of isolates was sequenced to either confirm identification or assist in further identification. Each isolate was grown on PCA for 4 days and, from these cultures, five $10-\mathrm{mm}$ plugs were placed in $50 \mathrm{ml}$ of dilute V8 broth (34) in a 125-ml Erlenmeyer flask for the production of mycelia. V8 broth cultures were incubated at $22^{\circ} \mathrm{C}$ in the dark for 7 days. Mycelium was collected on filter paper using a Buchner funnel, macerated using liquid nitrogen, collected in a $1.5-\mathrm{ml}$ microcentrofuge tube, and stored at $-20^{\circ} \mathrm{C}$ until used to extract DNA. The DNeasy plant minikit by Qiagen
(Qiagen Inc., Valencia, CA) was used to extract DNA according to the manufacturer's instructions. The DNA product was suspended in $100 \mu \mathrm{l}$ of sterile Tris-EDTA buffer and kept at $-20^{\circ} \mathrm{C}$ until ready for polymerase chain reaction (PCR).

The universal ITS primers ITS1 (TCC GTAGGTGAACCTGCGG) and ITS4 (TCCTCCGCTTATTGATATGC) were used to amplify a portion of the $18 \mathrm{~S}$ region, all of ITS1, the 5.8S region, ITS2, and a portion of the $28 \mathrm{~S}$ region of ribosomal DNA (41). A 50- $\mu$ reaction consisting of $10 \mu \mathrm{l}$ of $5 \times$ Green GoTaq Reaction buffer (Promega Corp., Madison, WI), $3 \mu \mathrm{l}$ of $25 \mathrm{mM} \mathrm{MgCl}_{2}, 2 \mu$ containing $4 \mathrm{mM}$ each dNTP, $0.5 \mu \mathrm{l}$ of Taq polymerase, $5 \mu \mathrm{l}$ each of a $5-\mu \mathrm{M}$ concentration of primers ITS1 (5'-tccgtaggtgaacetgcgg- $\left.3^{\prime}\right)$ and ITS4 (5'-tcctccgcttattgatatgc- $\left.3^{\prime}\right), 6 \mu \mathrm{l}$ of DNA at 1:10 dilution (one part DNA in Qiagen buffer $\mathrm{AE}$ to nine parts deionized filtersterilized $\mathrm{H}_{2} \mathrm{O}$ ), and $24.5 \mu \mathrm{l}$ of de-ionized, filter-sterilized water was carried out in a 0.2-ml thin-walled microcentrifuge tube. PCR parameters according to Moorman et al. (25) were $94^{\circ} \mathrm{C}$ for $5 \mathrm{~min}$; followed by 34 cycles of $94^{\circ} \mathrm{C}$ for $1 \mathrm{~min}, 53^{\circ} \mathrm{C}$ for 1 min, and $72^{\circ} \mathrm{C}$ for $1 \mathrm{~min}$; and completed with $72^{\circ} \mathrm{C}$ for $5 \mathrm{~min}$ followed by $4^{\circ} \mathrm{C}$. PCR products were purified using Qiaquick spin columns (Qiagen, Inc.). For sequencing, 3 $\mu \mathrm{l}$ of ITS 1 or ITS 4 at 2 pmoles/ $\mu$ were added to $5 \mu \mathrm{l}$ of purified DNA $(20 \mathrm{ng} / \mu \mathrm{l})$ product. Sequencing was done at the Molecular and Cellular Imaging Center at the Ohio Agricultural Research and Development Center (OARDC, Wooster). The basecalling software PHRED (University of Washington, Seattle) was used to convert the chromatogram data into sequences, which were aligned and edited using Sequencher 4.6 (Gene Codes Corporation, Ann Arbor, MI). Sequence data was compared with known sequences deposited in the National Center for Biotechnology Information (NCBI) nonredundant database to confirm morphological identification and assist with identification of isolates which did not produce all morphological traits.

To better understand the diversity of $P y$ thium spp. isolated from diseased corn and soybean in Ohio, a phylogenetic tree was constructed using the ITS1-5.8S-ITS2 sequence of at least one isolate of each species and each unassigned morphological group, similar to Lévesque and De Cock (20). The phylogenetic and molecular analyses were completed using MEGA version 3.1 (19). An alignment using ClustalW and an unweighted pair group method with arithmetic means analysis with all the ITS sequences and several ITS sequences from GenBank was performed. A bootstrap $50 \%$ majority-rule consensus tree generated using 1,000 replications also was included.

Using a BLAST search, $P$. ostracodes Drechs. and $P$. boreale R. L. Duanwere sequences were included from GenBank, as well as the ITS sequence of an isolate of P. chamaehyphon Sideris recovered from a wheat seedling in Ohio. These species were included because of their morphological and sequence similarity to the isolates in morphological group 3 and group 6. ITS sequences from GenBank of Phytophthora sojae Kaufmanm \& Gerdemann, $P$. cinnamomi Rands, and $P$. infestans (Mont.) de Bary also were included because of their previously demonstrated sequence similarity to Pythium spp. with proliferating sporangia (20). The ITS sequence of Aphanomyces euteiches Drechs. was used as the outgroup.

Pathogenicity assays. All of the isolates collected were tested for pathogenicity on both corn and soybean seed. A petri dish assay, similar to that used previously to evaluate pathogenicity and aggressiveness of Pythium and Rhizoctonia spp. on soybean $(9,28,43)$ and Pythium spp. on alfalfa (2) and corn (9), was used. Each isolate was grown on PCA for 4 days and a 3-mm plug was transferred to the center of an 8$\mathrm{cm}$-diameter petri plate containing $15 \mathrm{ml}$ of $2 \%$ WA. The isolates were allowed to colonize the plate for $72 \mathrm{~h}$. Ten seeds of either corn hybrid LG2540 (LG Seeds. Elmwood, IL) or soybean cv. Sloan were surface disinfested in a $0.525 \%$ sodium hypochlorite solution and then equally spaced around the plate, approximately 1 $\mathrm{cm}$ from the edge. Plates were incubated at $22^{\circ} \mathrm{C}$ in the dark for 7 days, then healthy seeds were counted. Plates were scored by counting the number of seeds that successfully germinated on inoculated plates compared with the number that germinated on the noninoculated plates. Seeds were considered to have successfully germinated if the radicle was $>1 \mathrm{~cm}$ long and was not visibly colonized by the pathogen. Each isolate was scored for pathogenicity based on the following rating scale: $0=100 \%$ germination with no symptoms of infection; $1=70$ to $99 \%$ germination with lesion formation on the roots; $2=30$ to $69 \%$ germination with coalesced lesions; and $3=0$ to $29 \%$ germination, where all seed tissues were colonized. Isolates were arranged in a randomized complete block design with replicates as individual blocks. There were three replicate plates for each isolate in each experiment and the experiment was conducted three times.

Because pathogenicity was evaluated using an ordinal rating scale, the data was analyzed using a nonparametric approach as described by Shah and Madden (35). In separate analyses using PROC MIXED of SAS (SAS Institute, Cary, NC), species and isolates were treated as fixed effects and the relative pathogenicity among species and isolates within species were compared using contrasts.

In addition to the in vitro pathogenicity assay, a greenhouse assay was used to 
complete Koch's postulates on species that were not previously reported as pathogens of corn or soybean. One isolate each of Pythium attrantheridium Allain-Boulé \& Lévesque, $P$. inflatum Matthews, $P$. dissotocum, an isolate of each mating type of $P$. sylvaticum W. A. Campbell \& J. W. Hendrix, and morphological group 3 and group 6 were evaluated in this greenhouse assay. Inoculum was produced using a modified protocol from Kirkpatrick et al. (18) by adding 105 -mm plugs of each isolate to a previously sterilized $500-\mathrm{ml}$ flask containing $237.5 \mathrm{~g}$ of sand, $12.5 \mathrm{~g}$ of cornmeal, and $80 \mathrm{ml}$ of deionized $\mathrm{H}_{2} \mathrm{O}$. Isolates were allowed to colonize the medium for 9 days, and flasks were shaken every other day to evenly disperse inoculum. Inoculum of each isolate then was transferred to three 500-ml styrofoam cups, and 10 corn (LG2540) and 10 soybean (Sloan) seeds were planted in each of three cups. Seeds were allowed to germinate and grow for 14 days, at which time seedlings were scored for the presence of lesions. Seedlings with lesions on either the seed, root, or shoot were plated on WA, and isolates were identified in the same manner as described previously.

Fungicide sensitivity. A subset, consisting of 58 Pythium isolates, representing all the species and collection sites, was used to assess baseline sensitivity to mefenoxam (ApronXL; Syngenta Crop Protection Inc., Greensboro NC), trifloxystrobin (Trilex; Gustafson LLC Plant, TX), azoxystrobin (Dynasty; Syngenta Crop Protection Inc.), and captan (Captan 400; Gustafson LLC). All fungicides were dissolved in deionized $\mathrm{H}_{2} \mathrm{O}$ to achieve the proper concentration of active ingredients and added to PCA after autoclaving, when the media had cooled to approximately $50^{\circ} \mathrm{C}$. Commercial-grade mefenoxam was evaluated at 5 and $100 \mu \mathrm{g}$ a.i./ml, and nonamended PCA was used for the control. Trifloxystrobin and azoxystrobin were evaluated at 1,10 , and $100 \mu \mathrm{g}$ a.i./ml of commercial-grade product. For the strobilurin fungicides, each concentration also was amended with salicylhydroxamic acid (SHAM) at $50 \mu \mathrm{g} / \mathrm{ml}$ to inhibit the action of the alternative oxidase respiratory pathway. Two controls were included for comparison with the strobilurin fungicides; the first was nonamended PCA and the second was PCA amended with SHAM at $50 \mu \mathrm{g} / \mathrm{ml}$. A preliminary experiment was completed to determine the amount of SHAM that would provide 20 to $40 \%$ inhibition of mycelial growth of all species. SHAM was dissolved in a 1:1 concentration of dimethylsulfoxide and methanol; amended to PCA at $0,25,50,75$, and 100 $\mu \mathrm{g} / \mathrm{ml}$; and evaluated in the same manner as the fungicides. Captan was evaluated at $50,100,200$, and $400 \mu \mathrm{g}$ a.i. $/ \mathrm{ml}$ of commercial-grade product, and nonamended PCA was used as the control.

For each isolate, a 3-mm-diameter plug from the edge of a 3- to 4-day-old colony was transferred to the center of each plate for each concentration of the fungicide evaluated. The colony diameter was measured in two places after $48 \mathrm{~h}$ for the fastgrowing species and $72 \mathrm{~h}$ for the slowgrowing species. The percent growth inhibition was calculated for each concentration by dividing the average colony diameter of the isolate, minus the $3 \mathrm{~mm}$ for the agar plug, by the average colony diameter of the nonfungicide-amended media, multiplied by 100 . For the strobilurin fungitration was compared with the colony diameter on PCA amended with SHAM at $50 \mu \mathrm{g} / \mathrm{ml}$ alone to calculate the percent mycelial growth of the control. The experimental design was a randomized complete block design with each replication separated over time, with at least $24 \mathrm{~h}$ between each replicate. Each isolate was evaluated at all fungicide concentrations and each isolate by concentration combination was each replication. Variation in sensitivity across species and among isolates of a species to the four different fungicides, as well as the effect of fungicide concentration and species on the efficacy of the four fungicides, were analyzed using PROC GLM of SAS (SAS Institute).

\section{RESULTS}

Pythium spp. isolation and identification. In all, 19 isolates of Pythium were recovered from 10 locations in 8 counties during 2004, and 105 isolates from 30 locations in 15 counties in Ohio and 2 locations in northeast Indiana during 2005. Of the 32 locations sampled during 2005, 4 were sampled extensively, providing 45 isolates. The other 60 isolates were recovered from diseased corn and soybean tissue from the remaining 28 locations. In total, 11 species ( $P$. attrantheridium, $P$. dissotocum, $P$. echinulatum Matthews, $P$. graminicola, P. inflatum, P. irregulare, P. helicides, the colony diameter at each concen-

coides Drechs., P. sylvaticum, P. torulosum, $P$. ultimum var. ultimum, and P. ultimum Trow var. sporangiiferum Drechs.) were identified by their morphological characteristics and confirmed by sequence analysis (Fig. 1). Two distinct morphological groups, designated group 3 and group 6, were identified but could not be assigned to species based on morphological characteristics or sequence data. Over the 2-year period, $P$. dissotocum and $P$. sylvaticum were the species most frequently recovered from both corn and soybean (Fig. 1), representing 23 and $20 \%$ (29 and 24 isolates) of the isolate collection, respectively.

Only one mating type of the heterothallic species $P$. attrantheridium was recovered. Isolates of this species on PCA had a chrysanthemum-like growth pattern, with main hyphae 3 to $4 \mu \mathrm{m}$ wide, abundant intercalary and terminal hyphal swellings ranging from 18 to $24 \mu \mathrm{m}$ in diameter, and bean-shaped appressoria, which sometimes occurred in chains. No oogonia, antheridia, or sporangia could be induced. The sequence data and the morphological traits indicated that all isolates in this group were of the negative mating strain (1).

Isolates of both morphological group 3 and group 6 possessed terminal, globose, internally proliferating sporangia. The sequence data suggested the isolates of morphological group 3 and group 6 were most closely related to other species with proliferating sporangia, such as $P$. ostracodes and $P$. boreale.

Analysis of the ITS sequence separated the different isolates recovered from Ohio soils into three major phylogenetic clades (Fig. 2). Clade A consisted of $P$. irregulare, $P$. sylvaticum, $P$. attrantheridium, $P$. ultimum var. ultimum, $P$. ultimum var. sporangiiferum, and $P$. echinulatum. Clade B was composed of $P$. graminicola, $P$. dissotocum, $P$. inflatum, and $P$. torulosum. The ITS sequences of the three Phytophthora

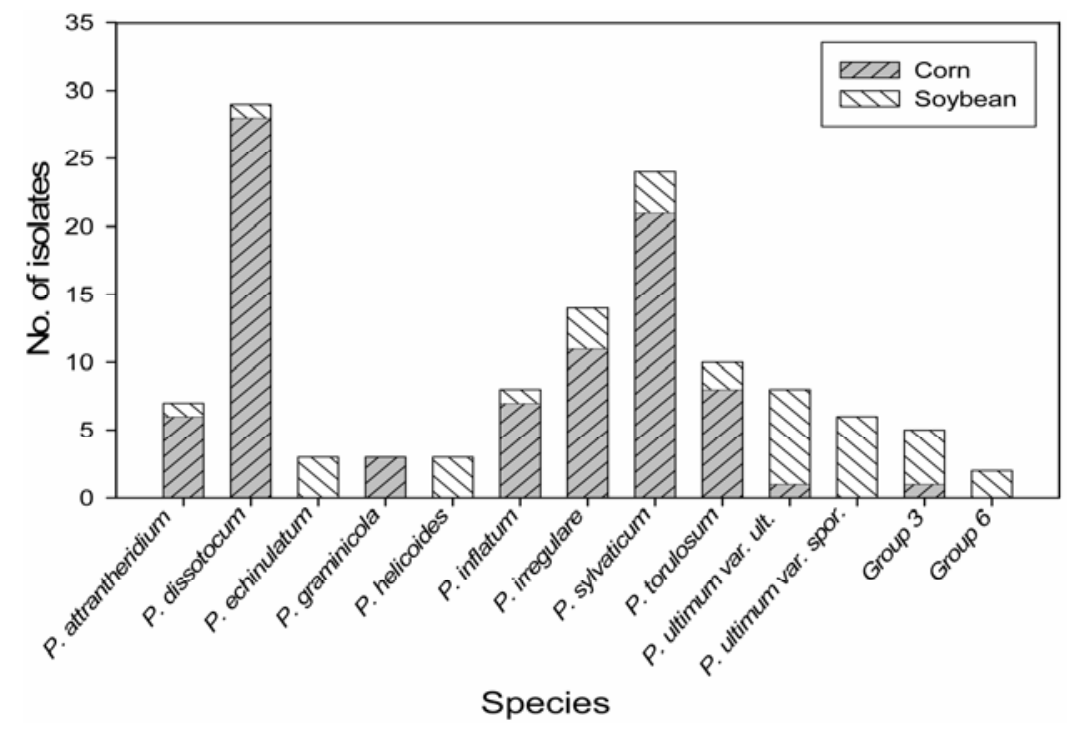

Fig. 1. Number of isolates of each Pythium sp. recovered in Ohio from either corn or soybean diseased root or shoot tissue during 2005 (105 isolates) or baited from soil during 2004 (19 isolates). 
spp., Phytophthora sojae, P. cinnamomi, and $P$. infestans imported from GenBank, formed Clade C. Group 3 and group 6 were included in clade D, along with $P y$ thium chameahyphon, $P$. helicoides, $P$. ostracodes, and P. boreale.
Pathogenicity assays. Isolates with a pathogenicity score from 0 to 1,1 to 2 , or 2 to 3 were considered to have a low, moderate, or high level of pathogenicity, respectively. All species of Pythium reduced germination of soybean more than corn

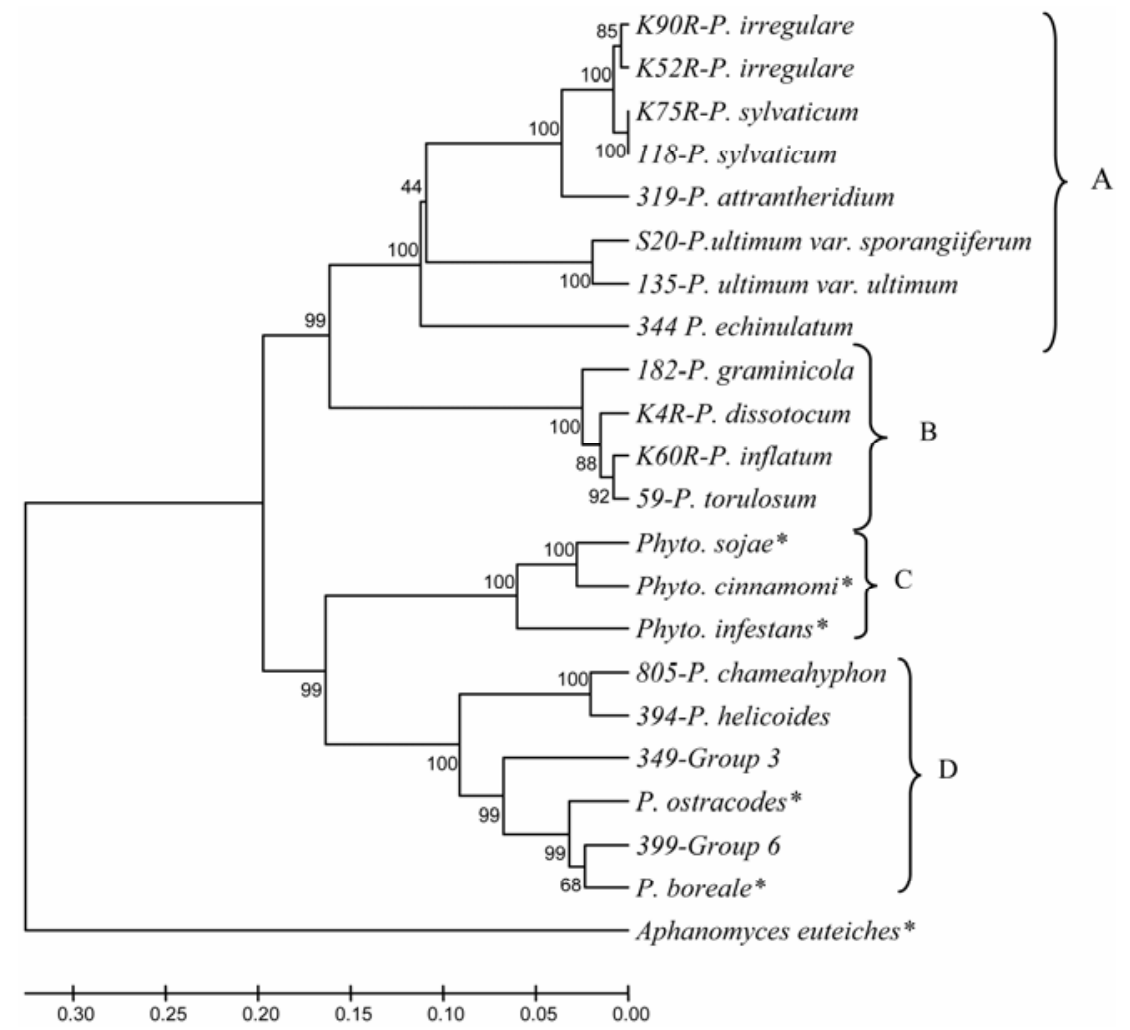

Fig. 2. Phylogeny of Pythium spp. based on internal transcribed spacer (ITS)1-5.8S-ITS2 sequence of nuclear rDNA. Numbers within the tree represent the bootstrap values (1,000 replications). Species with an isolate number in front of the species name were recovered from diseased corn or soybean tissue in Ohio., with the exception of Pythium chameahyphon, which was recovered from wheat seedlings in Ohio. Species names followed by an $(*)$ indicates that gene sequence data was imported from GenBank.

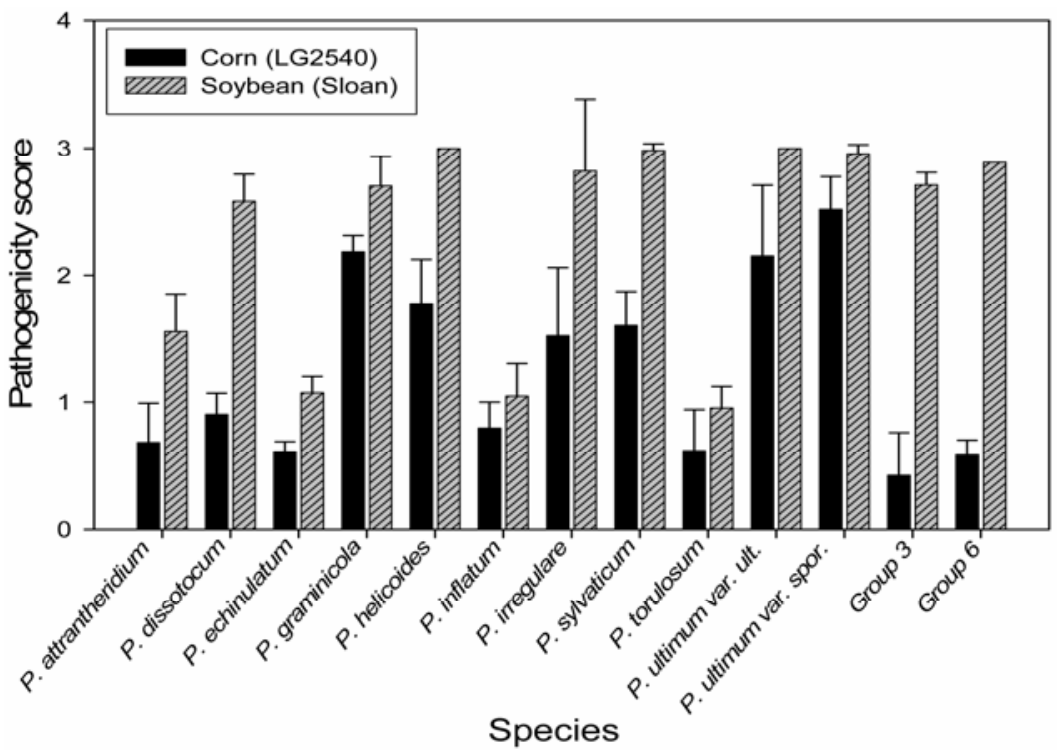

Fig. 3. Mean pathogenicity of 12 species of Pythium on corn and soybean seed. A petri plate assay was used to determine pathogenicity using a 0 -to-3 rating scale based on percent germination compared with the control. The rating was $0=100 \%$ germination with no symptom of infection, $1=70$ to $99 \%$ germination with lesion formation on roots, $2=30$ to $69 \%$ germination with coalesced lesions and reduced root growth, and $3=0$ to $29 \%$ germination with colonization of all seed.
(Fig. 3), and all species of Pythium were significantly $(P<0.001)$ more pathogenic on both corn and soybean than the control. However, there also was a significant $(P<$ $0.001)$ amount of variation among all species of Pythium. P. graminicola, P. ultimum var. ultimum, and $P$. ultimum var. sporangiiferum were highly pathogenic on both corn and soybean. P. sylvaticum isolates were highly pathogenic on soybean and moderately pathogenic on corn. P. dissotocum and morphological group 3 and group 6 were highly pathogenic on soybean, but had only a low level of pathogenicity on corn. P. inflatum, P. torulosum, P. echinulatum, and $P$. attrantheridium had lower pathogenicity scores on corn and soybean, but all were able to cause lesions on seedling roots. There was significant variation $(P<0.001)$ among isolates of $P$. irregulare for severity scores and for inhibition of seed germination. The isolates causing disease were highly pathogenic on soybean and moderately pathogenic on corn, whereas other isolates had low pathogenicity scores on both corn and soybean.

$P$. attrantheridium was able to infect both corn and soybean seedlings. Brown lesions developed on seedling roots as well as lesions on the root tips that restricted root growth. This species was recovered successfully from the diseased tissue upon reisolation. This is the first report of $P$. attrantheridium as a pathogen of both corn and soybean seedlings. In all, seven isolates of this species were recovered from six locations; six isolates were from diseased corn seedlings and one was from diseased soybean. $P$. inflatum was isolated from lesions on root tissue following inoculation of corn and soybean in the greenhouse assay. $P$. inflatum did not inhibit germination; however, small brown lesions were observed at the root tips of all plants and elongated lesions occasionally formed on the roots. This is also the first report of $P$. inflatum as a pathogen of both corn and soybean seedlings in the United States. Seven isolates of $P$. inflatum were recovered from diseased corn tissue from four different locations. Both mating types of $P$. sylvaticum were recovered from both seed and roots of diseased corn and soybean tissue in the greenhouse assay. $P$. sylvaticum was able to infect both seed and seedlings and had a negative impact on germination. In addition, $P$. dissotocum was isolated from root lesions of corn and from root lesions and seed of soybean. This is the first report of $P$. dissotocum as a seed and root pathogen of soybean. The isolates of morphological group 3 and group 6 also were able to cause lesions on both corn and soybean seedlings, and were reisolated from those lesions.

Fungicide sensitivity. There was a significant $(P<0.0001)$ main effect of species and fungicide concentration and species-concentration interaction on the efficacy of mefenoxam, azoxystrobin, and 
captan on the mycelial growth of Pythium spp. (Table 1). There was a significant $(P<$ $0.0001)$ main effect of species for trifloxystrobin on Pythium spp. growth but not concentration. From the subset of $58 \mathrm{Py}$ thium isolates evaluated, the sensitivity to mefenoxam, trifloxystrobin, azoxystrobin, and captan varied across species (Table 2) and also among isolates within a species (Tables 3 and 4). Sensitivity to mefenoxam ranged from 0 to $47 \%$ growth of the con- trol at $100 \mu \mathrm{g} / \mathrm{ml}$. Species with filamentous sporangia ( $P$. graminicola, $P$. dissotocum, $P$. inflatum, and $P$. torulosum) and species with proliferating sporangia (morphological group 3 and group 6) were significantly $(P<0.05)$ less sensitive to mefenoxam than species with globose sporangia $(P$. irregulare, $P$. ultimum var. ultimum, $P$. sylvaticum, $P$. attrantheridium, and $P$. echinulatum) (Fig. 4). In addition, P. irregulare, P. ultimum var. ultimum, P. sylvati- cum, $P$ attrantheridium, group 3 , and group 6 were significantly $(P<0.05)$ less sensitive to azoxystrobin (Fig. 5) and trifloxystrobin (Fig. 6) than P. graminicola, $P$. dissotocum, $P$. inflatum, and $P$. torulosum. Sensitivity to azoxystrobin and trifloxystrobin ranged from 0 to 28 and 0 to $87 \%$ growth of the control at $100 \mu \mathrm{g} / \mathrm{ml}$, respectively. Sensitivity to captan ranged from 0 to $8 \%$ growth of the control at 400 $\mu \mathrm{g} / \mathrm{ml}$, and $P$. inflatum, $P$. torulosum, and $P$.

Table 1. $F$ values and $P$ statistics for effects of Pythium spp., fungicide concentration, and experiment on mycelial growth in plate assays

\begin{tabular}{|c|c|c|c|c|c|c|c|c|c|c|c|c|}
\hline \multirow[b]{2}{*}{ Source } & \multicolumn{3}{|c|}{ Mefenoxam } & \multicolumn{3}{|c|}{ Azoxystrobin } & \multicolumn{3}{|c|}{ Trifloxystrobin } & \multicolumn{3}{|c|}{ Captan } \\
\hline & df & $F$ value & $P$ & df & $F$ value & $P$ & df & $F$ value & $P$ & df & $F$ value & $P$ \\
\hline Species $(S)^{x}$ & 11 & 124.36 & $<0.0001$ & 11 & 82.50 & $<0.0001$ & 11 & 469.41 & $<0.0001$ & 11 & 96.68 & $<0.0001$ \\
\hline Concentration $(C)^{y}$ & 1 & 79.84 & $<0.0001$ & 2 & 78.10 & $<0.0001$ & 2 & 2.73 & 0.0600 & 3 & 251.61 & $<0.0001$ \\
\hline $\mathrm{S} \times \mathrm{C}$ & 11 & 7.08 & $<0.0001$ & 22 & 7.94 & $<0.0001$ & 22 & 1.16 & 0.2848 & 33 & 14.64 & $<0.0001$ \\
\hline Experiment $(E)^{\mathrm{Z}}$ & 2 & 0.07 & 0.9282 & 2 & 0.24 & 0.7871 & 2 & 0.08 & 0.9225 & 2 & 1.52 & 0.2200 \\
\hline $\mathrm{S} \times \mathrm{E}$ & 22 & 0.16 & 1.0000 & 22 & 0.14 & 1.0000 & 22 & 0.94 & 0.5429 & 22 & 0.67 & 0.8722 \\
\hline $\mathrm{C} \times \mathrm{E}$ & 2 & 0.66 & 0.5177 & 4 & 0.07 & 0.9922 & 4 & 0.82 & 0.5133 & 6 & 0.35 & 0.9105 \\
\hline $\mathrm{S} \times \mathrm{C} \times \mathrm{E}$ & 22 & 0.40 & 0.9933 & 44 & 0.07 & 1.0000 & 44 & 0.47 & 0.9985 & 66 & 0.14 & 1.0000 \\
\hline
\end{tabular}

$\mathrm{x}$ In all, 60 isolates representing nine different species and two distinct morphological groups were used to evaluate the efficacy of all four fungicides.

y Mefenoxam was evaluated at 5 and $100 \mu \mathrm{g}$ a.i./ml; azoxystrobin and trifloxystrobin were evaluated at 1,10 , and $100 \mu \mathrm{g}$ a.i./ml; and captan was evaluated at 50, 100, 200, and $400 \mu \mathrm{g}$ a.i./ml.

$\mathrm{z}$ The experimental design was a complete randomized block design with three replications separated over time, with at least $24 \mathrm{~h}$ between replications.

Table 2. Growth of 12 species of Pythium evaluated on media amended with the active ingredients of four different fungicide seed treatments

\begin{tabular}{|c|c|c|c|c|c|c|c|c|}
\hline \multirow[b]{3}{*}{ Species $^{z}$} & \multicolumn{8}{|c|}{ Fungicide $^{x}$} \\
\hline & \multicolumn{2}{|c|}{ Mefenoxam } & \multicolumn{2}{|c|}{ Azoxystrobin ${ }^{y}$} & \multicolumn{2}{|c|}{ Trifloxystrobin ${ }^{y}$} & \multicolumn{2}{|c|}{ Captan } \\
\hline & $5 \mu \mathrm{g} / \mathrm{ml}$ & $100 \mu \mathrm{g} / \mathrm{ml}$ & $10 \mu \mathrm{g} / \mathrm{ml}$ & $100 \mu \mathrm{g} / \mathrm{ml}$ & $10 \mu \mathrm{g} / \mathrm{ml}$ & $100 \mu \mathrm{g} / \mathrm{ml}$ & $50 \mu \mathrm{g} / \mathrm{ml}$ & $200 \mu \mathrm{g} / \mathrm{ml}$ \\
\hline Group 6 (2) & $54.7 \mathrm{a}$ & $47.0 \mathrm{a}$ & $34.2 \mathrm{a}$ & $19.1 \mathrm{bc}$ & $65.9 \mathrm{bc}$ & $67.3 \mathrm{c}$ & $12.1 \mathrm{c}$ & $1.4 \mathrm{~b}$ \\
\hline Group 3 (4) & $32.1 \mathrm{~b}$ & $18.3 \mathrm{~b}$ & $36.4 \mathrm{a}$ & $24.0 \mathrm{ab}$ & $53.7 \mathrm{~cd}$ & $55.8 \mathrm{~d}$ & $25.6 \mathrm{bc}$ & $3.6 \mathrm{~b}$ \\
\hline Pythium graminicola (2) & $27.5 \mathrm{bc}$ & $16.0 \mathrm{~b}$ & $0.0 \mathrm{e}$ & $0.0 \mathrm{~d}$ & $39.1 \mathrm{e}$ & $36.3 \mathrm{e}$ & $18.0 \mathrm{ab}$ & $4.2 \mathrm{~b}$ \\
\hline P. dissotocum (9) & $25.1 \mathrm{~cd}$ & $12.6 \mathrm{~b}$ & $1.8 \mathrm{e}$ & $0.5 \mathrm{~d}$ & 34.7 ef & 33.8 ef & $40.9 \mathrm{ab}$ & $14.5 \mathrm{a}$ \\
\hline P. inflatum (5) & $19.6 \mathrm{~d}$ & $4.7 \mathrm{c}$ & $0.0 \mathrm{e}$ & $0.0 \mathrm{~d}$ & $22.4 \mathrm{f}$ & $19.6 \mathrm{~g}$ & $48.2 \mathrm{a}$ & $20.5 \mathrm{a}$ \\
\hline P. torulosum (5) & $12.0 \mathrm{e}$ & $1.9 \mathrm{c}$ & $0.0 \mathrm{e}$ & $0.0 \mathrm{~d}$ & $1.1 \mathrm{~g}$ & $0.0 \mathrm{~h}$ & $43.8 \mathrm{a}$ & $16.4 \mathrm{a}$ \\
\hline P. helicoides (1) & $4.8 \mathrm{f}$ & $0.8 \mathrm{c}$ & $23.5 \mathrm{c}$ & $26.3 \mathrm{a}$ & $70.0 \mathrm{ab}$ & $75.6 \mathrm{bc}$ & $11.4 \mathrm{c}$ & $0.9 \mathrm{~b}$ \\
\hline P. irregulare (4) & $3.5 \mathrm{f}$ & $1.4 \mathrm{c}$ & $34.2 \mathrm{a}$ & $26.8 \mathrm{a}$ & $83.1 \mathrm{a}$ & $82.0 \mathrm{ab}$ & $20.2 \mathrm{c}$ & $1.5 \mathrm{~b}$ \\
\hline P. sylvaticum (11) & $3.4 \mathrm{f}$ & $1.4 \mathrm{c}$ & $23.5 \mathrm{c}$ & $18.3 \mathrm{c}$ & $73.5 \mathrm{ab}$ & $74.8 \mathrm{bc}$ & $13.6 \mathrm{c}$ & $2.3 \mathrm{~b}$ \\
\hline P. ultimum (8) & $2.5 \mathrm{f}$ & $0.7 \mathrm{c}$ & $27.5 \mathrm{~b}$ & $23.1 \mathrm{abc}$ & $72.0 \mathrm{ab}$ & $73.5 \mathrm{bc}$ & $13.1 \mathrm{c}$ & $1.2 \mathrm{~b}$ \\
\hline P. attrantheridium (4) & $1.9 \mathrm{f}$ & $0.0 \mathrm{c}$ & $12.2 \mathrm{~d}$ & $1.1 \mathrm{~d}$ & $80.8 \mathrm{a}$ & $87.6 \mathrm{a}$ & $11.2 \mathrm{c}$ & $2.3 \mathrm{~b}$ \\
\hline P. echinulatum (3) & $0.0 \mathrm{f}$ & $0.0 \mathrm{c}$ & $0.0 \mathrm{e}$ & $0.0 \mathrm{~d}$ & $23.7 \mathrm{f}$ & $25.4 \mathrm{fg}$ & $0.5 \mathrm{c}$ & $0.0 \mathrm{~b}$ \\
\hline
\end{tabular}

$\mathrm{x}$ Values are the mean percent growth of the control for a species. Values in a column followed by the same letter are not significantly different according to

Fisher's protected least significant difference $(P<0.05)$.

y Salicylhydroxamic acid (SHAM) was added to all concentrations of azoxystrbin and trifloxystrobin at $50 \mu \mathrm{g} / \mathrm{ml}$ to inhibit the action of the alternative oxidase pathway; SHAM at $50 \mu \mathrm{g} / \mathrm{ml}$ also was added to the control.

${ }^{\mathrm{z}}$ Values in parenthesis represent the number of isolates of each species evaluated on all four fungicides.

Table 3. Growth of nine isolates of Pythium dissotocum on media amended with four fungicides used as seed treatments

\begin{tabular}{|c|c|c|c|c|c|c|c|c|}
\hline \multirow[b]{3}{*}{ Isolate } & \multicolumn{8}{|c|}{ Fungicide $^{y}$} \\
\hline & \multicolumn{2}{|c|}{ Mefenoxam } & \multicolumn{2}{|c|}{ Azoxystrobin ${ }^{z}$} & \multicolumn{2}{|c|}{ Trifloxystrobin ${ }^{z}$} & \multicolumn{2}{|c|}{ Captan } \\
\hline & $5 \mu \mathrm{g} / \mathrm{ml}$ & $100 \mu \mathrm{g} / \mathrm{ml}$ & $10 \mu \mathrm{g} / \mathrm{ml}$ & $100 \mu \mathrm{g} / \mathrm{ml}$ & $10 \mu \mathrm{g} / \mathrm{ml}$ & $100 \mu \mathrm{g} / \mathrm{ml}$ & $50 \mu \mathrm{g} / \mathrm{ml}$ & $200 \mu \mathrm{g} / \mathrm{ml}$ \\
\hline 347 & $46.1 \mathrm{a}$ & $25.2 \mathrm{a}$ & $0.0 \mathrm{~b}$ & $0.0 \mathrm{a}$ & $35.5 \mathrm{a}$ & $33.3 \mathrm{ab}$ & $42.6 \mathrm{bc}$ & $14.7 \mathrm{bc}$ \\
\hline K104R & $41.9 \mathrm{a}$ & $12.6 \mathrm{bc}$ & $0.0 \mathrm{~b}$ & $0.0 \mathrm{a}$ & $31.1 \mathrm{ab}$ & $27.7 \mathrm{abc}$ & $33.1 \mathrm{de}$ & $13.1 \mathrm{bc}$ \\
\hline K23R & $39.7 \mathrm{a}$ & $18.2 \mathrm{~b}$ & $0.0 \mathrm{~b}$ & $0.0 \mathrm{a}$ & $34.0 \mathrm{ab}$ & $36.1 \mathrm{a}$ & $31.7 \mathrm{e}$ & $12.9 \mathrm{bc}$ \\
\hline K4R & $26.4 \mathrm{~b}$ & $10.9 \mathrm{~cd}$ & $2.6 \mathrm{a}$ & $0.0 \mathrm{a}$ & $34.7 \mathrm{a}$ & $31.8 \mathrm{ab}$ & 37.4 cde & $13.0 \mathrm{bc}$ \\
\hline 156 & $17.2 \mathrm{c}$ & $14.6 \mathrm{bc}$ & $0.0 \mathrm{~b}$ & $0.0 \mathrm{a}$ & $22.6 \mathrm{~b}$ & $22.6 \mathrm{bc}$ & $49.6 \mathrm{ab}$ & $22.6 \mathrm{a}$ \\
\hline 237 & $16.2 \mathrm{c}$ & $11.8 \mathrm{c}$ & $0.0 \mathrm{~b}$ & $0.0 \mathrm{a}$ & $34.5 \mathrm{a}$ & $30.8 \mathrm{abc}$ & $34.2 \mathrm{de}$ & $13.4 \mathrm{bc}$ \\
\hline K65R & $13.0 \mathrm{c}$ & $5.4 \mathrm{de}$ & $0.0 \mathrm{~b}$ & $0.0 \mathrm{a}$ & $30.7 \mathrm{ab}$ & $29.9 \mathrm{abc}$ & $49.9 \mathrm{ab}$ & $19.3 \mathrm{ab}$ \\
\hline 226 & $12.7 \mathrm{c}$ & $4.7 \mathrm{e}$ & $0.0 \mathrm{~b}$ & $0.0 \mathrm{a}$ & $29.2 \mathrm{ab}$ & $18.5 \mathrm{c}$ & $54.7 \mathrm{a}$ & $23.7 \mathrm{a}$ \\
\hline 115 & $12.4 \mathrm{c}$ & $10.5 \mathrm{cde}$ & $2.0 \mathrm{ab}$ & $0.0 \mathrm{a}$ & $31.6 \mathrm{ab}$ & $31.6 \mathrm{abc}$ & $40.2 \mathrm{~cd}$ & $11.5 \mathrm{c}$ \\
\hline Mean & 25.1 & 12.8 & 0.5 & 0.0 & 31.5 & 29.1 & 41.62 & 16.06 \\
\hline
\end{tabular}

y Values are the mean percent growth of the control averaged across three replications for each isolate. Values in a column followed by the same letter are not significantly different according to Fisher's protected least significant difference $(P<0.05)$.

${ }^{\mathrm{z}}$ Salicylhydroxamic acid was added to all concentrations of azoxystrobin, trifoxystrobin, and a nonfungicide-amended control at $50 \mu \mathrm{g} / \mathrm{ml}$ to inhibit the action of the alternative oxidase pathway. 
dissotocum were significantly $(P<0.05)$ less sensitive than the other nine species evaluated (Fig. 7). There was a significant $(P<0.001)$ effect of concentration on the efficacy of SHAM and there also was significant $(P<0.001)$ variation in the sensitivity among species of Pythium (Fig. 8). Sensitivity to SHAM ranged from 49 to 89 and 8 to $53 \%$ growth of the control at 50 and $100 \mu \mathrm{g} / \mathrm{ml}$, respectively. Based on these results, $50 \mu \mathrm{g} / \mathrm{ml}$ was the rate of SHAM incorporated to inhibit the alternative oxidase in media amended with azoxystrobin or trifloxystrobin.

\section{DISCUSSION}

In Ohio, the most common practice to manage pre- and post-emergence dampingoff is through the application of fungicide seed treatments. However, a diverse range of Pythium spp. have been known to cause both seed and root rot of corn and soybean $(30,43)$ and this investigation confirms that a variety of Pythium spp. have the capacity to reduce germination and cause lesions on roots of corn and soybean seed and seedlings in Ohio. Many species of Pythium from other states and in previous studies in Ohio have been reported as pathogens of corn and soybean, but this is the first report of both $P$. attrantheridium and $P$. inflatum as pathogens of corn and soybean.

The petri plate pathogenicity assay is an effective method for determining the pathogenic capability of species of $P y$ thium. Those species considered moderately to highly pathogenic may be the primary pathogens, and may have the capacity to cause large reductions in stand by themselves. Similar plate assays were used previously to identify resistance to Pythium spp. in alfalfa (2), as well as evaluate fungicide seed treatments on corn seedlings for the control of Fusarium spp. (27). Therefore, the petri plate method may prove useful in the future for evaluating different corn and soybean lines for resistance to multiple species of Pythium. The greenhouse assay also demonstrated the wide range of pathogenicity among these species of Pythium. Some species, such as $P$. inflatum and $P$. attrantheridium, caused lesions only on the roots, whereas other species, such as $P$. sylvaticum and $P$. dissotocum, were able to infect the entire root system, mesocotyl, coleoptile, and hypocotyl, and penetrate the seed coat. However, even species with low levels of pathogenicity had the ability to cause lesions, most generally on the root tip. These less-pathogenic species may not be able to significantly reduce germination or plant stand by themselves, but they may reduce overall size and function of the roots and potentially provide an infection court for other soilborne pathogens such as Fusarium, Rhizoctonia, and other Pythium spp. $P$. irregulare has been associated with Fusarium acuminatum and Phoma ter- restris in causing red root rot of corn (22) and Pythium ulitmum, along with Rhizoctonia and Fusarium spp., compose a disease complex causing preemergence damping-off of the soybean cv. Essex reported in Virginia (11).

There was variation in pathogenicity among isolates of a species, specifically $P$. irregulare, which consisted of highly pathogenic isolates and less-pathogenic isolates. Recently $P$. irregulare was reported to be composed of two cryptic species, which may account for differences in pathogenicity among isolates in our study (10). P. irregulare isolates $\mathrm{K} 34 \mathrm{R}, \mathrm{K} 52 \mathrm{R}$, and K90R, which were moderately to highly pathogenic on both corn and soybean, were used for sequence analysis and, when aligned with several isolates from the study by Garzon et al. (10), were grouped with two different isolates of $P$.

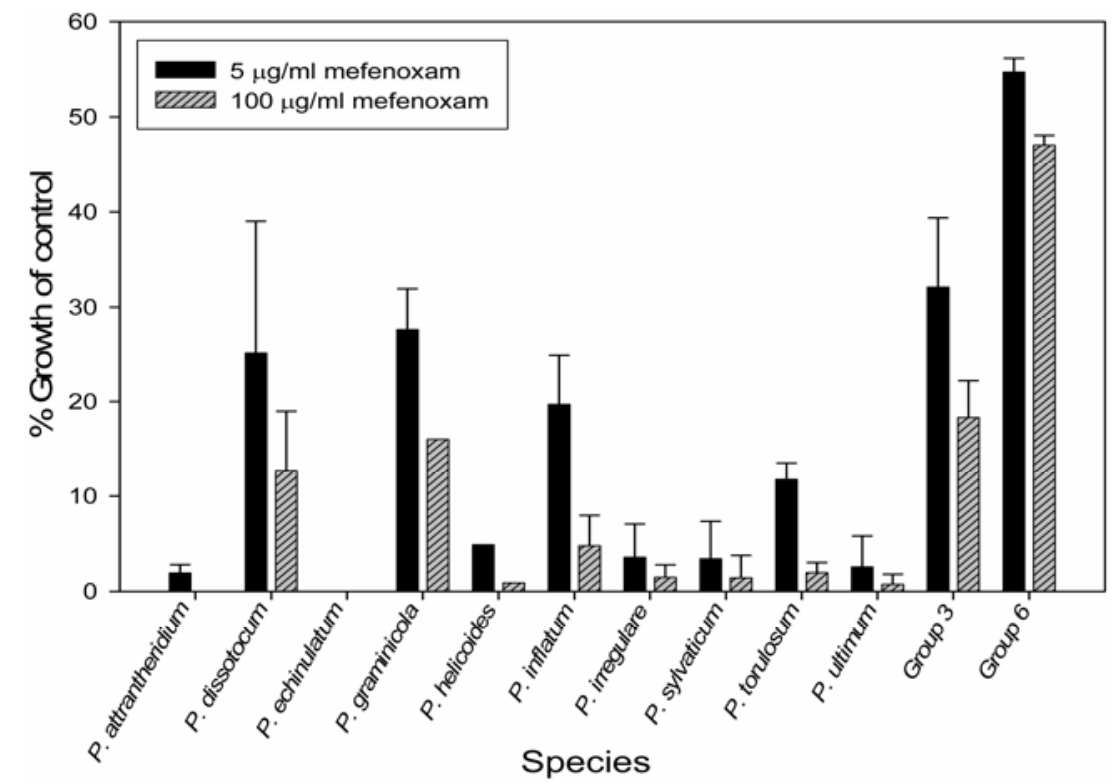

Fig. 4. Growth of 12 Pythium spp. on media amended with mefenoxam at 5 and $100 \mu \mathrm{g} / \mathrm{ml}$. The mycelial growth of each isolate at each concentration was divided by the growth on the nonfungicideamended control to determine the percent mycelial growth.

Table 4. Growth of 11 isolates of Pythium sylvaticum on media amended with four fungicides used as seed treatments

\begin{tabular}{|c|c|c|c|c|c|c|c|c|}
\hline \multirow[b]{3}{*}{ Isolate } & \multicolumn{8}{|c|}{ Fungicide $^{y}$} \\
\hline & \multicolumn{2}{|c|}{ Mefenoxam } & \multicolumn{2}{|c|}{ Azoxystrobin $^{z}$} & \multicolumn{2}{|c|}{ Trifloxystrobin $^{z}$} & \multicolumn{2}{|c|}{ Captan } \\
\hline & $5 \mu \mathrm{g} / \mathrm{ml}$ & $100 \mu \mathrm{g} / \mathrm{ml}$ & $10 \mu \mathrm{g} / \mathrm{ml}$ & $100 \mu \mathrm{g} / \mathrm{ml}$ & $10 \mu \mathrm{g} / \mathrm{ml}$ & $100 \mu \mathrm{g} / \mathrm{ml}$ & $50 \mu \mathrm{g} / \mathrm{ml}$ & $200 \mu \mathrm{g} / \mathrm{ml}$ \\
\hline 118 & $12.4 \mathrm{a}$ & $8.0 \mathrm{a}$ & $18.4 \mathrm{~b}$ & $17.3 \mathrm{bc}$ & $69.3 \mathrm{~b}$ & $70.6 \mathrm{a}$ & $7.4 \mathrm{c}$ & $0.6 \mathrm{bc}$ \\
\hline 134 & $9.7 \mathrm{ab}$ & $4.0 \mathrm{ab}$ & $16.8 \mathrm{~b}$ & $14.4 \mathrm{c}$ & $74.3 \mathrm{ab}$ & $78.2 \mathrm{a}$ & $20.6 \mathrm{a}$ & $2.9 \mathrm{abc}$ \\
\hline 46 & $4.8 \mathrm{bc}$ & $0.0 \mathrm{~b}$ & $22.6 \mathrm{ab}$ & $17.4 \mathrm{bc}$ & $73.4 \mathrm{ab}$ & $71.6 \mathrm{a}$ & $22.7 \mathrm{a}$ & $7.3 \mathrm{a}$ \\
\hline 210 & $2.2 \mathrm{c}$ & $0.8 \mathrm{~b}$ & $17.9 \mathrm{~b}$ & $26.3 \mathrm{a}$ & $76.4 \mathrm{ab}$ & $78.3 \mathrm{a}$ & $2.3 \mathrm{c}$ & $1.2 \mathrm{bc}$ \\
\hline 199 & $1.7 \mathrm{c}$ & $0.0 \mathrm{~b}$ & $27.6 \mathrm{ab}$ & $20.2 a b c$ & $73.5 \mathrm{ab}$ & $75.5 \mathrm{a}$ & $1.7 \mathrm{c}$ & $0.5 \mathrm{bc}$ \\
\hline K11R & $1.6 \mathrm{c}$ & $0.8 \mathrm{~b}$ & $35.6 \mathrm{a}$ & $23.4 \mathrm{ab}$ & $79.9 \mathrm{a}$ & $78.7 \mathrm{a}$ & $23.0 \mathrm{a}$ & $3.9 \mathrm{abc}$ \\
\hline K75R & $0.8 \mathrm{c}$ & $0.0 \mathrm{~b}$ & $27.2 \mathrm{ab}$ & $24.8 \mathrm{ab}$ & $74.0 \mathrm{a}$ & $75.2 \mathrm{a}$ & $18.4 \mathrm{a}$ & $1.2 \mathrm{bc}$ \\
\hline 329 & $0.8 \mathrm{c}$ & $0.8 \mathrm{~b}$ & $19.7 \mathrm{ab}$ & $13.7 \mathrm{c}$ & $75.5 \mathrm{ab}$ & $78.7 \mathrm{a}$ & $8.2 \mathrm{bc}$ & $2.0 \mathrm{bc}$ \\
\hline 168 & $0.0 \mathrm{c}$ & $0.0 \mathrm{~b}$ & $18.1 \mathrm{~b}$ & $13.9 \mathrm{c}$ & $67.5 \mathrm{~b}$ & $67.0 \mathrm{a}$ & $5.8 \mathrm{c}$ & $0.6 \mathrm{bc}$ \\
\hline 362 & $0.0 \mathrm{c}$ & $0.0 \mathrm{~b}$ & $29.9 \mathrm{ab}$ & $20.9 a b c$ & $73.4 \mathrm{ab}$ & $73.5 \mathrm{a}$ & $6.8 \mathrm{c}$ & $0.0 \mathrm{c}$ \\
\hline 360 & $0.0 \mathrm{c}$ & $0.8 \mathrm{~b}$ & $25.0 \mathrm{ab}$ & $16.4 \mathrm{bc}$ & $70.7 \mathrm{ab}$ & $71.8 \mathrm{a}$ & $16.5 \mathrm{ab}$ & $5.1 \mathrm{ab}$ \\
\hline Mean & 3.1 & 1.4 & 23.5 & 19.0 & 73.5 & 74.5 & 12.1 & 2.3 \\
\hline
\end{tabular}

${ }^{y}$ Values are the mean percent growth of the control averaged across three replications for each isolate. Values in a column followed by the same letter are not significantly different, according to Fisher's protected least significant difference $(P<0.05)$.

${ }^{\mathrm{z}}$ Salicylhydroxamic acid was added to all concentrations of azoxystrobin, trifloxystrobin, and nonfungicide-amended control at $50 \mu \mathrm{g} / \mathrm{ml}$ to inhibit the action of the alternative oxidase pathway. 
irregulare sensu stricto. It is difficult to determine the role of genetic diversity on pathogenicity within this species, because only three isolates were sequenced in this study; however, genetic diversity may in part explain the significant variation in pathogenicity among isolates of $P$. irregulare.

The results of this study indicate that $P$. sylvaticum and $P$. dissotocum may be two of the more important seed and seedling pathogens associated with corn and soybean in Ohio. This is based on the frequency of recovery, the number of locations where these species were recovered, the high level of pathogenicity of $P$. sylvaticum on both corn and soybean, and the insensitivity of $P$. dissotocum to mefenoxam and $P$. sylvaticum to azoxystrobin. However, the frequency at which these two species were recovered may have more to do with their ability to grow well on the media used to make isolations. $P$. sylvaticum grows very rapidly and may have been preferentially isolated from diseased tissue. Regardless, $P$. sylvaticum is highly pathogenic on both corn and soybean seed, indicating its importance in reducing germination. $P$. dissotocum also appears to be important because of its relative insensitivity to mefenoxam, the most frequently used seed-treatment fungicide. In the past, $P$. dissotocum was not reported as being of great importance as a seed and seedling pathogen of corn and soybean in Ohio, although it was present. The continued use of mefenoxam as a seed treatment possibly may select for species with decreased sensitivity, such as $P$. dissotocum, $P$. inflatum, $P$. torulosum, and $P$. graminicola, causing a shift in species composition in corn and soybean fields, especially in those fields with persistent problems of substantial stand loss.

The phylogenetic analysis divided the species of Pythium recovered from Ohio into three different clades corresponding to sporangia morphology, which agrees with previous phylogenetic trees generated by Lévesque and De Cock (20). The phylogenetic tree also suggests that morphological group 3 and group 6 are more closely related to Phytophthora spp. than species of Pythium possessing filamentous or globose sporangia. Both morphological group 3 and group 6 isolates produced large (25 to $35 \mu \mathrm{m})$ terminal sporangia that proliferate internally, but both produced zoospores in a vesicle characteristic of Pythium spp., which distinguishes them from Phytophthora spp. Most importantly, the phylogenetic analysis demonstrates the wide range of genetic diversity among species of Pythium present in Ohio soybean and corn fields. It also is interesting to point out that there were species of Pythium from all three of the major clades that had a moderate to high level of pathogenicity on both corn and soybean.

None of the four fungicides evaluated had the capacity to inhibit the growth of all the Pythium spp. in this study. In addition, all species of Pythium did not respond to each of the four fungicides in the same manner, which agrees with an earlier study by Kato et al. (17). They evaluated the sensitivity of several Pythium spp. and other oomycetes to hymexazol and metalaxyl and found that different species of Pythium had a range of sensitivities to both metalaxyl and hymexazol. In this study, there appears to be an association with sporangia morphology and response to fungicides. Species with globose spo- rangia (clade A) were less sensitive to the strobilurins than species with filamentous sporangia (clade B). However, in contrast, species with filamentous sporangia were significantly less sensitive to mefenoxam than species with globose sporangia. Morphological group 3 and group 6 , with proliferating sporangia, also responded differently than species with filamentous or globose sporangia and had increased levels of insensitivity to both mefenoxam and strobilurin fungicides. Conversely, the lowest level of variability among species

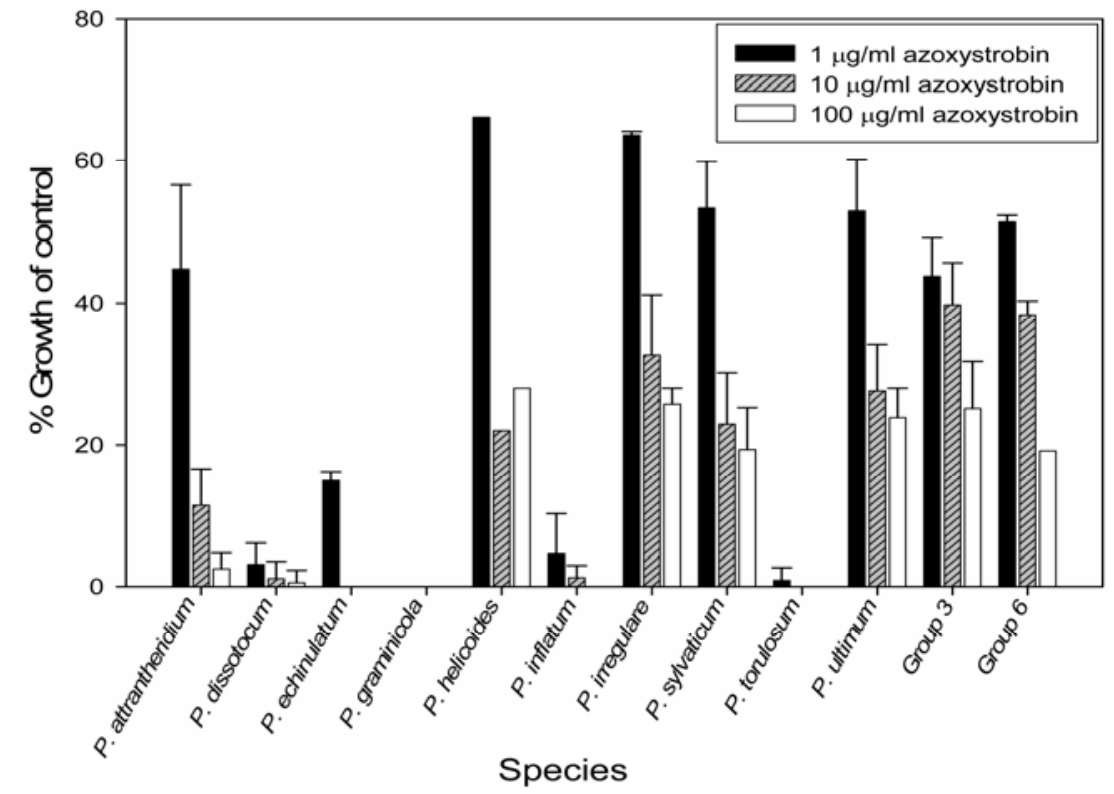

Fig. 5. Growth of 12 Pythium spp. on media amended with azoxystrobin at 1,10 , and $100 \mu \mathrm{g} / \mathrm{ml}$. All concentrations, including the control, contained salicylhydroxamic acid at $50 \mu \mathrm{g} / \mathrm{ml}$ to inhibit the activity of the alternative oxidase pathway. The mycelial growth of each isolate at each concentration was divided by the growth on the nonfungicide-amended control to determine the percent mycelial growth.

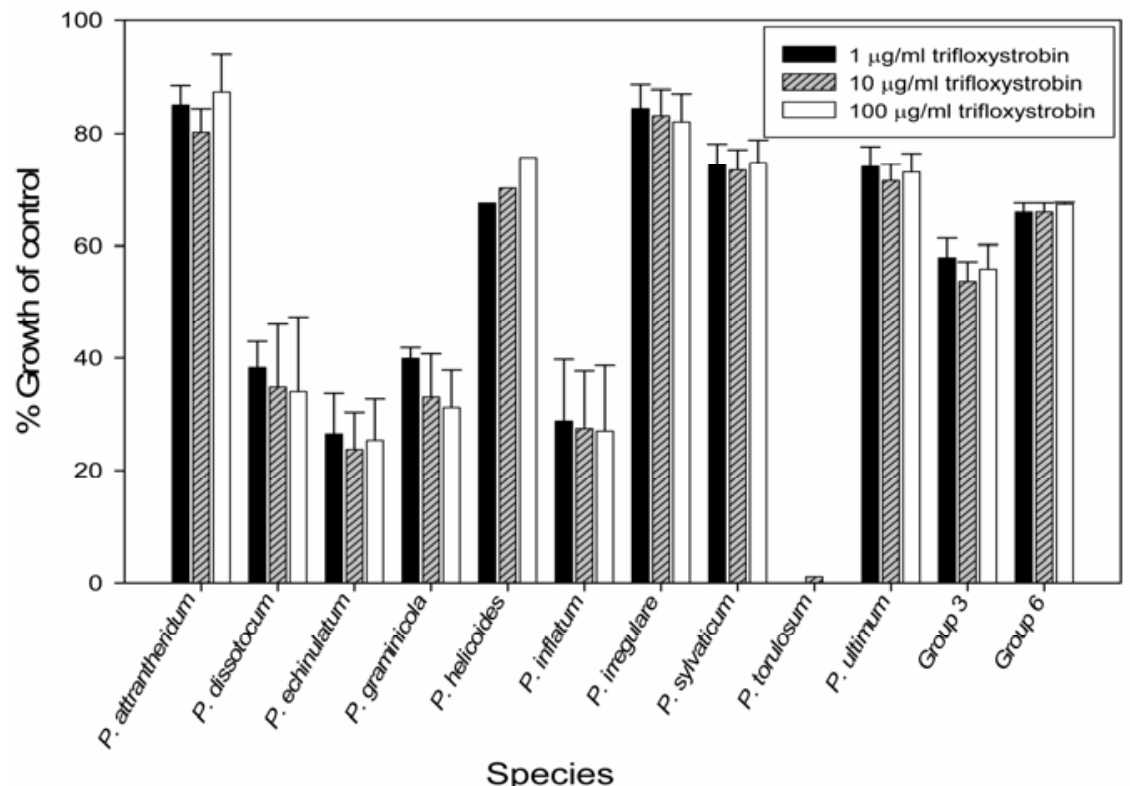

Fig. 6. Growth of 12 Pythium spp. on media amended with trifloxystrobin at 1, 10, and $100 \mu \mathrm{g} / \mathrm{ml}$. All concentrations, including the control, contained salicylhydroxamic acid at $50 \mu \mathrm{g} / \mathrm{ml}$ to inhibit the activity of the alternative oxidase pathway. The mycelial growth of each isolate at each concentration was divided by the growth on the nonfungicide-amended control to determine the percent mycelial growth. 
of Pythium to a fungicide was with captan at $200 \mu \mathrm{g} / \mathrm{ml}$. Minimum and maximum amounts of active ingredient of captan applied per seed when using the range of the recommended dose on the label was calculated to be 100 and $200 \mu \mathrm{g} / \mathrm{ml}$, respectively. Mycelial growth was only 7 and $2.7 \%$ of the control for morphological group 3 and group 6, respectively, at 100 $\mu \mathrm{g} / \mathrm{ml}$. In addition, only $P$. dissotocum, $P$. inflatum, and $P$. torulosum had mycelial with captan at $200 \mu \mathrm{g} / \mathrm{ml}$.

It is difficult to determine whether this shift from older, broad-spectrum mode of growth greater than $10 \%$ of the control

action fungicides to new, site-specific mode of action fungicides has led to an increase in pre- and post-emergence damping-off caused by species resistant or insensitive to these newer fungicide chemistries. In any case, the results from this study suggest that soybean and corn being planted in areas with a history of emergence problems caused by Pythium spp. should use a combination of fungicides to provide protection against several different species of Pythium, because these different species may be insensitive to one or more fungicides. It is this diversity which makes it difficult to manage all species of $P y$ -

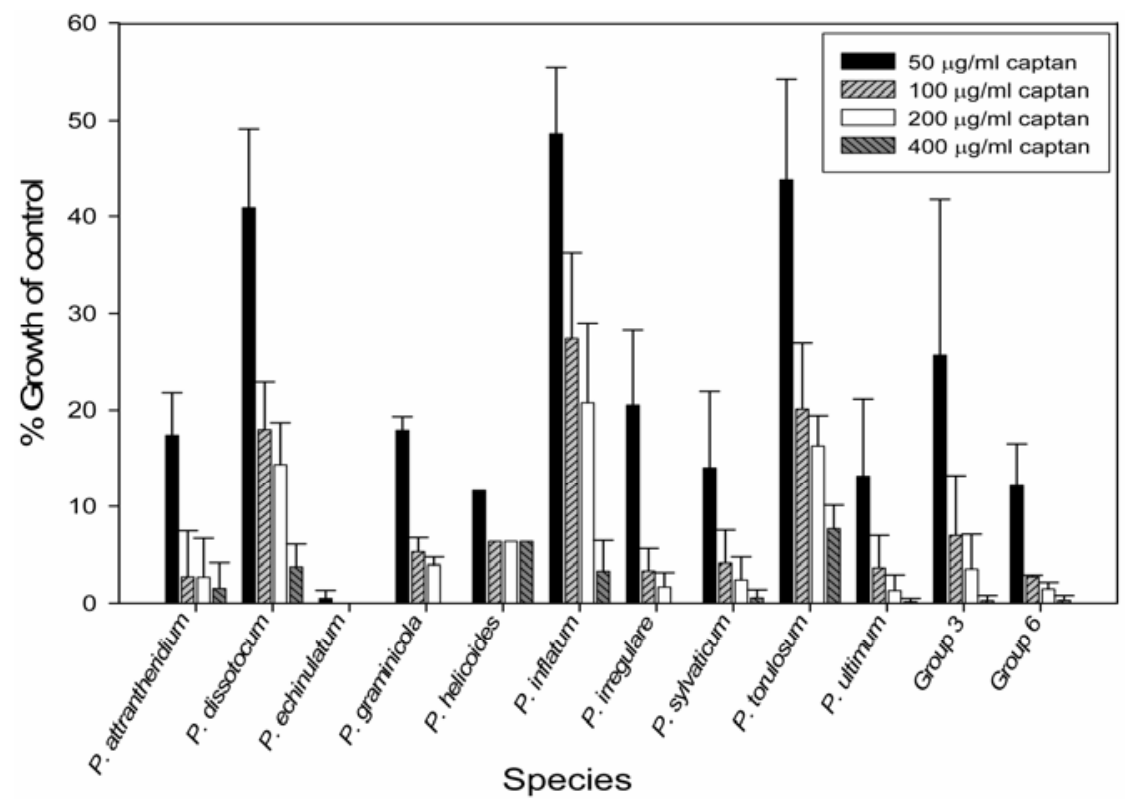

Fig. 7. Growth of 12 Pythium spp. on media amended with captan at 50, 100, 200, and $400 \mu \mathrm{g} / \mathrm{ml}$. The mycelial growth of each isolate at each concentration was divided by the growth on the nonfungicideamended control to determine the percent mycelial growth.

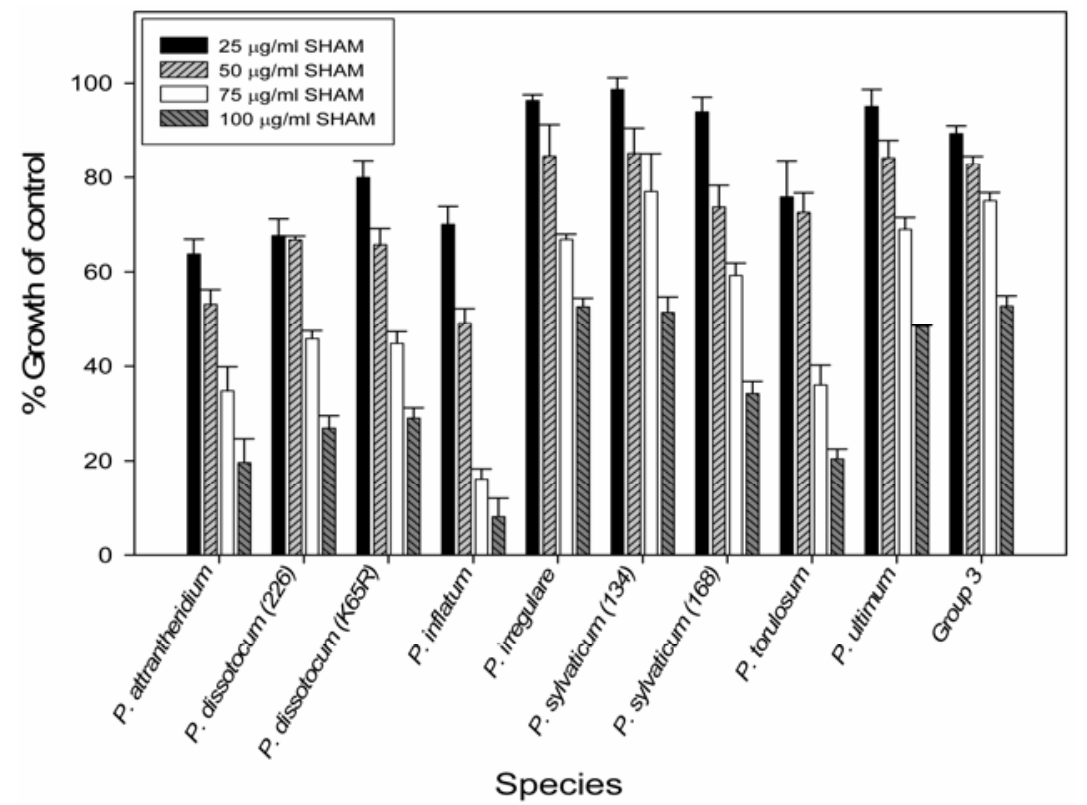

Fig. 8. Growth of 10 isolates of Pythium on salicylhydroxamic acid (SHAM) amended to potato-carrot agar at $25,50,75$, and $100 \mu \mathrm{g} / \mathrm{ml}$. The mycelial growth of each isolate at each concentration was divided by the growth on the nonamended control to determine the percent mycelial growth. thium associated with corn and soybean seedling disease with a single seedtreatment fungicide, and integrated management strategies such as improving drainage and planting only after soil temperatures have reached $10^{\circ} \mathrm{C}$ may need to be used along with multiple fungicide chemistries in areas with a history of substantial stand loss.

\section{ACKNOWLEDGMENTS}

Salaries and research support were provided by State and Federal Funds appropriated to the Ohio Agricultural Research and Development Center, The Ohio State University. This work was supported in part by Pioneer Crop Management Research Awards Program and OARDC Matching Grants Program. We thank A. Johnston, S. A. Berry, and F. Cruz for technical assistance; J. Belizzi for collection of isolates in 2004; J. Win for discussions and assistance with sequence and phylogenetic analyses; and the MCIC for assistance with sequencing.

\section{LITERATURE CITED}

1. Allain-Boule, N., Tweddell, T., Mazzola, M., Belanger, R., and Lévesque, A. 2004. Pythium attrantheridium sp. nov.: taxonomy and comparison with related species. Mycol. Res. 108:795-805.

2. Altier, N. A., and Thies, J. A. 1995. Identification of resistance to Pythium seedling diseases in alfalfa using a culture plate method. Plant Dis. 79:341-346.

3. Avila-Adame, C., and Koller, W. 2003. Impact of alternative respiration and target-site mutations on responses of germinating conidia of Magnaporthe grisea to Qo-inhibiting fungicides. Pest Manage. Sci. 59:303-309.

4. Brantner, J. R., and Windels, C. E. 1998. Variability in sensitivity to metalaxyl in vitro, pathogenicity, and control of Pythium spp. on sugar beet. Plant Dis. 82:896-899.

5. Brown, G. E., and Kennedy, B. W. 1965. Pythium pre-emergence damping-off of soybean in Minnesota. Plant Dis. Rep. 49:646-647.

6. Cook, R. J., and Zhang, B. X. 1985. Degrees of sensitivity to metalaxyl within the Pythium spp. pathogenic to wheat in the Pacific Northwest. Plant Dis. 69:686-688

7. Deep, I. W., and Lipps, P. E. 1996. Recovery of Pythium arrhenomanes and its virulence to corn. Crop Prot. 15:85-90.

8. Dodd, J. L., and White, D. G. 1999. Seed rot, seedling blight, and damping-off. In: Compendium of Corn Diseases. D. G. White, ed American Phytopathological Society, St. Paul, $\mathrm{MN}$.

9. Dorrance, A. E., Berry, S. A., Bowen, P., and Lipps, P. E. 2004. Characterization of Pythium spp. from three Ohio fields for pathogenicity on corn and soybean and metalaxyl sensitivity. Plant Heath Progress. Plant Management Network. Online publication.

10. Garzon, C. D., Geiser, D. M., and Moorman, G. W. 2005. Amplified fragment length polymorphism analysis and internal transcibed spacer and coxII sequences reveal a species boundary within Pythium irregulare. Plant Dis. 95:1489-1498.

11. Griffin, G. J. 1990. Importance of Pythium ultimum in a disease syndrome of cv. Essex soybean. Can. J. of Plant Pathol. 12:134-140.

12. Griffith, D. R., Mannering, J. V., and Moldenhauer, W. C. 1977. Conservation tillage in the eastern corn belt. J. Soil Water Conserv. 32:2028.

13. Guiterrez Chapin, L. J., Wang, Y., Lutton, E., and McSpadden Gardener, B. B. 2006 Distribution and fungicide sensitivity of fungal pathogens causing anthracnose-like lesions on tomatoes grown in Ohio. Plant 
Dis. 90:397-403.

14. Higginbotham, R. W., Paulitz, T. C., and Kidwell, K. K. 2004. Virulence of Pythium species isolated from wheat fields in eastern Washington. Plant Dis. 88:1021-1026.

15. Joseph-Horne, T., Wood, P. M., Heppner, C., and Holloman, D. 1999. Involvement of the alternative oxidase in cellular energy production in the wheat 'take all' fungus, Gaeumannomyces graminis var. tritici. Pestic. Sci. 55:367370.

16. Joseph-Horne, T., Wood, P. M., Wood, C. K., Moore, A. L., Headrick, J., and Holloman, D. 1998. Characterization of split respiratory pathway in the wheat 'take-all' fungus, Gaeumannomyces graminis var. tritici. J. Biol. Chem. 273:11127-11133.

17. Kato, S., Coe, R., New, L., and Dick, M. W. 1990. Sensitivities of various Oomycetes to hymexazol and metalaxyl. J. Gen. Microbiol. 136:2127-2134.

18. Kirkpatrick, M. T., Rothrock, C. S., Rupe, J. C., and Gbur, E. E. 2006. The effect of Pythium ultimum and soil flooding on two soybean cultivars. Plant Dis. 90:597-602.

19. Kumar, S. Tamura, K., and Nei, M. 2004. MEGA3: Integrated software for molecular evolutionary analysis and sequence alignment. Brief. Bioinformatics 5:150-163.

20. Lévesque, C .A., and De Cook, W. A. M. 2004. Molecular phylogeny and taxonomy of the genus Pythium. Mycol. Res. 108:1363-1383.

21. Lipps, P. E., and Deep, I. W. 1991. Influence of tillage and crop rotation on yield, stalk rot, and recovery of Fusarium and Trichoderma spp. from corn. Plant Dis. 75:828-833.

22. Mao, W., Carroll, R. B., and Whittington, D. P. 1998. Association of Phoma terrestris, Pythium irregulare, and Fusarium acuminatum in causing red root rot of corn. Plant Dis. 82:337342 .

23. Middleton, J. T. 1943. The taxonomy, host range and geographical distribution of the genus Pythium. Published for the Club by Lan- caster Press, Lancaster, PA.

24. Mondal, S. N., Bhatia, A., Shilts, T., and Timmer, L. W. 2005. Baseline sensitivities of fungal pathogens of fruit and foliage of citrus to azoxystrobin, pyraclostrobin, and fenbuconazole. Plant Dis. 89:1186-1194.

25. Moorman, G. W., Kang, S., Geiser, D. M., and Kim, S. H. 2002. Identification and characterization of Pythium species associated with greenhouse flora crops in Pennsylvania. Plant Dis. 86:1227.

26. Moorman, G. W., and Kim, S. H. 2004. Species of Pythium from greenhouses in Pennsylvania exhibit resistance to propamocarb and mefenoxam. Plant Dis. 88:630-632.

27. Munkvold, G. P. and O'Mara, J. K. 2002. Laboratory and growth chamber evaluation of fungicidal seed treatments for maize seedling blight caused by Fusarium species. Plant Dis. 86:143-149.

28. Muyolo, N. G., Lipps, P. E., and Schmitthenner, A. F. 1993. Anastomosis grouping and variation in virulence among isolates of Rhizoctonia solani associated with dry bean and soybean in Ohio and Zaire. Phytopathology 83:438-444.

29. Pankhurst, C. E., McDonald, H. J., and Hawke, B. G. 1995. Influence of tillage and crop rotation on the epidemiology of Pythium infections of wheat in red-brown earth of south Australia. Soil Biol. Biochem. 27:1065-1073.

30. Rao, B., Schmitthenner, A. F., Caldwell, R., and Ellett, C. W. 1978. Prevalence and virulence of Pythium species associated with root rot of corn in poorly drained soil. Phytopathology 68:1557-1563.

31. Reuveni, M., and Sheglov, D. 2002. Effects of azoxystrobin, difenoconazole, polyoxin B (polar) and trifloxystrobin on germination and growth of Alternaria alternata and decay in red delicious apple fruit. Crop Prot. 21:951955.

32. Rizvi, S. S. A., and Yang, X. B. 1996. Fungi associated with soybean seedling disease in
Iowa. Plant Dis. 80:57-60.

33. Saab, I. 2005. Stress emergence in corn. Crop Insights 5:1-4.

34. Schmitthenner, A. F., and Bhat, R. G. 1994. Useful methods for studying Phytophthora in the laboratory. Plant Pathol. Ohio Agric. Res. Dev. Cent. Spec. Circ. 143.

35. Shah, D. A., and Madden, L. V. 2004. Nonparametric analysis of ordinal data in designed factorial experiments. Phytopathology 94:3343.

36. Steinfeld, U., Sierotzki, H., Parisi, S., Poirey, S., and Gisi, U. 2001. Sensitivity of mitochondrial respiration to different inhibitors in Venturia inaequalis. Pest Manage. Sci. 57:787796.

37. Taylor, R. J., Salas, B., Secor, G. A., Rivera, V., and Gudmestad, N. C. 2002. Sensitivity of North American isolates of Phytophthora erythroseptica and Pythium ultimum to mefenoxam (metalaxyl). Plant Dis. 86:797-802.

38. van der Plaats-Niterink, A. J. 1981. Monograph of the Genus Pythium. Studies in Mycology No. 21, Centraalbureau voor Schimmelculture, Baarn, The Netherlands.

39. Van Doren D. M., Jr., and Triplett, G. B., Jr. 1973. Mulch and tillage relationships in corn culture. Soil Sci. Soc. Am. Proc. 37:766-769.

40. Waterhouse, G. M. 1967. Key to Pythium Pringsheim. Mycol. Pap. 109:1-15.

41. White, T. J., Bruns, T., Lee, S., and Taylor, J. 1990. Amplification and direct sequencing of fungal ribosomal RNA genes for phylogenetics. In: PCR Protocols: A Guide to Methods and Applications. M. A. Innis, D. H. Gelfand, and J. J. Snisky, eds. Academic Press, Inc. New York.

42. Ypema, H. L., and Gold, R. E. 1999 Kresoxim-methyl: modification of a naturally occurring compound to produce a new fungicide. Plant Dis. 83:4-18

43. Zhang, B. Q., and Yang, X. B. 2000. Pathogenicity of Pythium populations from cornsoybean rotation fields. Plant Dis. 84:94-99. 